\title{
The impact of household size on poverty: An analysis of various low-income townships in the Northern Free State region, South Africa
}

\author{
Daniel Francois Meyer \& Rachel Nishimwe-Niyimbanira \\ Faculty of Economic Sciences and IT, North-West University, Vanderbijlpark, South Africa \\ Email: Daniel.meyer@nwu.ac.za
}

\begin{abstract}
Poverty is a multi-dimensional socio-economic problem in most sub-Saharan African countries. The purpose of this study is to analyse the relationship between household size and poverty in low-income communities. The Northern Free State region in South Africa was selected as the study region. A sample of approximately 2900 households was randomly selected within 12 poor communities in the region. A poverty line was calculated and $74 \%$ of all households were found to live below the poverty line. The Pearson's chi-square test indicated a positive relationship between household size and poverty in eleven of the twelve low-income communities. Households below the poverty line presented larger households than those households above the poverty line. This finding is in contradiction with some findings in other African countries due to the fact that South Africa has higher levels of modernisation with less access to land for subsistence farming. Effective provision of basic needs, community facilities and access to assets such as land could assist poor households with better quality of life. Poor households also need to be granted access to economic opportunities, while also receiving adult education regarding financial management and reproductive health.
\end{abstract}

Keywords: poverty, household size, low-income communities, Northern Free State, South Africa.

\section{Résumé}

La pauvreté est un problème socio-économique multidimensionnel dans la plupart des pays de l'Afrique Sub-Saharienne. Le but de cette étude est d'analyser des rapports entre la taille du ménage et la pauvreté dans des communautés à faible revenu. Le nord de la province de Free State en Afrique du Sud a été choisi pour cette étude. Un échantillon environ de 2900 ménages a été aléatoirement sélectionné dans 12 communautés pauvres de la région. Apres avoir calculé un seuil de pauvreté monétaire, on a constaté que $74 \%$ de tous les ménages vivent en dessous du seuil de pauvreté. Le test de Khi-deux de Pearson a indiqué un rapport positif entre la taille du ménage et la pauvreté sur onze parmi les 12 communautés pauvres. La pauvreté est accentuée particulièrement parmi les ménages de large taille par rapport aux ménages de petite taille. Ces résultats obtenus contredisent quelques résultats dans d'autres pays Africains par le fait qu'en Afrique du Sud la modernisation est très avancés avec moins d'accès à la terre pour l'agriculture de subsistance. Une efficace fourniture des besoins de base, les aménagements communautaires et l'accès à des actifs tels que la terre pourraient aider les ménages pauvres de mener une meilleure vie. Les ménages pauvres ont également besoins d'accès aux opportunités économiques, à part de l'éducation en matière de la gestion financière et la santé reproductive.

Mots clés : pauvreté, la taille du ménage, communautés avec un faible revenu, Free State nord, Afrique du sud. 


\section{Introduction}

Research has shown that the size of households have been declining over the last century in both developed and developing countries (OECD, 20II). The number of households, although smaller households, have shown faster growth rates if compared to the overall global population growth (Bradbury et al., 20l4). However, developing countries with low levels of economic activity, limited modernisation activities, and a dominating subsistence-farming sector, still present large household sizes. Research on household size and its relationship with poverty, over the last few decades, has led to interesting research results and findings. The literature on the impact of household size on the levels of poverty is still divided but leaning towards a positive correlation between size of the household and poverty, but with a negative impact of household size on levels of poverty (Schiller, 1995; Orbeta, 2005; Virola \& Martinez, 2007).

The initial hypothesis of this study is that large households have an increased chance of being poor if compared to smaller households as found by the United Nations Population Fund (1999). If conclusive evidence could be collected in the study region as selected, this initial hypothesis could be confirmed or rejected. The findings of this research could assist in improved policy development and amendment in the study region. The household is the smallest economic unit, and reduction of poverty at grassroots level could lead to overall poverty reduction in communities.

The research methodology followed in this study was quantitative in nature. Household surveys were conducted in 12 poor communities in the Northern Free State region, South Africa. A large sample of approximately 2900 households was included to ensure a comprehensive and representative survey sample.

\section{Literature review}

Poverty is a complex, multi-dimensional, and universal socio-economic problem (United Nations, 2009). Many Sub-Saharan countries, including South Africa, are tormented with extensive and deeply rooted poverty. South Africa is regarded as an "upper-middle-income" country by the World Bank (World Bank, 20I4), but up to $50 \%$ of South African households are living in poverty, or at the least are vulnerable to be exposed to poverty (Poswa, 2008).

The reasons for this phenomena in South Africa are numerous and diverse. One of the main reasons for the high levels of poverty in South Africa is the now defunct apartheid system, which ended in 1994. One of the features of this system of racial segregation was the procedure of active dispossession, whereby assets, such as livestock and land, were confiscated from black people leading to deep levels of poverty which is still evident today (May \& Norton, 1997). Asset accumulation assists with wealth creation. Opportunities to build up such assets, through education, infrastructure and markets, were denied to people during the period from 1948 to 1994 (May \& Norton, 1997). Other reasons for the high levels of poverty in South Africa are lack of access to opportunities, high levels of unemployment, lack of basic services and basic needs, and limited access to land (SPII, 2007).

At household level, there is a relationship between the household size and level of poverty (Woolard \& Klasen, 2005). Poverty could be alleviated and gross domestic product (GDP) per capita could be increased if proper macro-economic policies are applied. The United Nations Population Fund (1999) claimed, with evidence, that when families have fewer children, it contributes to accelerated development and reduction of poverty at the household and the macro-economic level. However, population growth and household size per se, are not necessarily negative for development. Virola and Martinez (2007) argued that population growth might be good for certain countries, especially developing countries at a particular phase of development. Developed countries such as Germany, are now encouraging its population to have more children, which is in contrast with previous policies of low population growth. Such policy needs to be accompanied by relatively high levels of economic growth. However, Orbeta (2005) argues that the debate on the role of population growth and household size in poverty is unresolved.

Rakodi (1995) states that many predictors for poverty in households exist including size of household, income, dependency ratio and subsistence activities. She also states that smaller households relates to higher per capita income. Households can attempt many strategies to reduce poverty such as increase income, diversify activities for income and production, improved level of resources and relationships, and access to land. Woman generally are worse off than men and policy needs to be in place to address this issue.

According to Perlman (1976), there are various factors that are associated at the household or individual level such as level of education, household size and structure, dependency ratio, health, race, gender, age and labour force status/income. These household demographic factors determine to a large extent poverty status. According to Mullahy and Wolfe (2000), inadequate access to basic needs which includes housing may cause such households to be 
unable to function as an effective unit, making them vulnerable, leading to poverty.

The main purpose of this study is to investigate the most basic unit of the South African economy, namely the household, regarding the relationship between household size and poverty. The authors of this paper accept that household size is definitely not the only determinant of poverty, but only one of many factors such as income and lack of basic needs. A household is described as a group of people (could also be a single person) whose food provision, shelter and other essentials for living are done in common (Bongaarts, 200I). Definitions of households differ significantly among countries (Bongaarts, 200I). For the purpose of this article, a household consists of the number of persons usually residing in the household and sharing household expenses (Kamuzora, 200I). In a survey of poor households as reported by the South African-Participatory Poverty Assessment (PPA), poor people themselves describe poverty factors as isolation from the community, a lack of security, low wages, a lack of employment opportunities, poor nutrition, poor access to water, having too many children, poor education opportunities and the misuse of resources (May et al., 1998). Considering this definition, one can conclude that the number of household members is an important demographic feature of any country or region, and is recognised as one of the causes of poverty.

According to Widyanti et al., (2009), the key determinants which increase the likelihood of a state of poverty at the household level, as far as household size and composition is concerned, include: the movement of family members in and out of households resulting in increases or decreases in the dependency ratio, the mortality rate, the number of children, the number of grandchildren, the gender of members and household structure such as single parent and elderly-headed households, and whether the household is a member of a marginalised group, inter alia a disadvantaged ethnic group or the disabled. Anyanwu (2013) claims that the productivity of female parents may be affected by newly-born infants; either by hindering her work prospects, or needing more resources such as nourishment. In many sub-Saharan African countries where there are low savings and absence of well-developed social security systems, parents tends to increase fertility rates, especially among the poor as insurance against old age (Anyanwu, 20I3). Parents may decide to have more children to increase the probability of getting support from them when they will reach old age, increased social grants and subsidy from government. High infant mortality rates amongst the poor tend to provoke excess replacement births, as survival rates are low and there is the belief that children are gifts from God, leading to high birth rates (Anyanwu, 2013).

Individuals within households have distinct characteristics such as economic capacity, which eventually define the economic capacity of the household as a unit. The presence of a link between economic capacity of a household and its composition could be a vital point in explaining why certain households fall into poverty or not. It is possible that some household compositions, which produce a great difference between households' earning capacity and its consumption needs, are the fundamental factors for poverty. Generally, a larger household size means larger expenditures for food, shelter, clothing, health, education and other needs (Virola \& Martinez, 2007). The above aspects depend on the dependency ratio of a household.

The literature contains an abundance of evidence indicating that large households in poor communities are linked to higher levels of poverty (Lanjouw \& Ravallion, 1995; Jalan \& Ravallion, 1998; Klasen, 2000; Woolard \& Klasen, 2005; Baiyegunhi \& Fraser, 2010; Sekhampu, 20/3). Performing censored conditional quintile estimations on panel data for post-reform in rural China, Jalan and Ravalion (1998), investigated the link between household composition and geographic determinants of chronic and transient poverty. One of their findings indicates that smaller and better-educated households have less chronic poverty. Particularly they found that an increase in household size is likely to put an extra burden on the household and is expected to have a positive relationship with chronic poverty. White and Masset (2003) found a positive relationship between poverty and household size in Vietnam but that the relationship could not be applied as a general rule. Factors that impact on the relationship are gender (woman-headed households are poorer), education (lower level of education of household members leads to poorer families) and geographical locality (rural households generally poorer). The findings were confirmed by Bigsten et al., (2003) in a case study in Ethiopia. This inverse relationship between household size and poverty has been confirmed by a number of other research findings for example in Cambodia (Kanbur et al,. 2003), in Uganda by Okurut et al., (2002), in Brazil by Fishlow (1972), in Malaysia by Anand (1977), in India by Dubey et al., (1999) and in Pakistan by the World Bank (1990).

Various researchers in this research field have listed a number of reasons for the continuous reduction in household sizes in both developed and developing countries. Some of the reasons include the overall improvement of people's economic situation with increased income levels, reduced 
fertility, increased housing prices (Micheal et al., 1980; Borsch-Supan, 1986), improved technology and modernisation (Latour, 2004), more elderly people in

households (Klinenberg, 20I2) and higher incidence of family problems such as divorce ( $\mathrm{Yu}$ \& Lin, 2007). According to Koulovatianos et al., (2010) on the micro level, households that are economically better off, seems to cope better as smaller households. On the macro level, a reduction in household sizes could lead to an increase in material needs per capita and a growth in needs.

The impact of household size on the poverty status of households in South Africa has been also highlighted in many studies where large households were found to be associated with an increased probability of being poor (Baiyegunhi \& Fraser, 2010;
Sekhampu, 2013). Three poverty traps that hamper the poor in moving out of poverty, found by Woolard and Klasen's (2005) study on income mobility and household dynamics, involve a large initial household size, low levels of education, and poor initial participation in the labour market. Table I provides minimum levels of income per household as determined by Schwabe (2004) for 200I in South Africa. The minimum income levels were adjusted to also indicate 2013 income levels. The table shows that the income per person in a household decreases as the household size increases. However, it also indicates that larger households need more income than smaller households to stay clear of poverty. Poverty is calculated by using the $\$ 2$ per day poverty line as used by the United Nations (UN).

Table I: Minimum income levels per household in South Africa, 200 I to 2013

\begin{tabular}{|l|l|l|}
\hline $\begin{array}{l}\text { Household size } \\
\text { (number of people) }\end{array}$ & $\begin{array}{l}\text { 200I (the amount in brackets is per } \\
\text { person) }\end{array}$ & $\begin{array}{l}\text { 20I3 (the amount in brackets is per } \\
\text { person) }\end{array}$ \\
\hline I & R 587 (R 587) & R II74 (R II 74) \\
\hline 2 & R 733 (R 387) & R I546 (R 773) \\
\hline 3 & R I028 (R 343) & R 2056 (R 685) \\
\hline 4 & R I290 (R 323) & R 259I (R 648) \\
\hline 5 & R I54I (R 308) & R 3082 (R 6I6) \\
\hline 6 & R I806 (R 30I) & R 36I2 (R 602) \\
\hline 7 & R 2054 (R 293) & R 4I08 (R 587) \\
\hline
\end{tabular}

Source: Schwabe, (2004) as amended by authors.

In a report by the World Bank (1995), it was found in South Africa that large households with many dependents are likely to be poor. Poor households are also generally larger than non-poor households, with associated higher dependency ratios. Schiller (1995) agrees with the World Bank findings, and states that large households with a high number of dependents are more likely to be poor.

However, Widyanti et al., (2009) argued that the relationship between poverty and household size can be positive or negative. Ahlburgh (1998) and Easterlin (1967) indicated an unclear relationship between poverty and household size. They argued that a change in the economic condition of a household could encourage the household to restructure its composition. For instance, an improvement in a household's economic and financial condition can induce the household to have more children or support extended family members, while a decline in economic status may compel the household to decrease its size by asking some household members to move out. In rural Tanzania, Kamuzora and Gwalema (1998) made two intriguing findings regarding the relationship between poverty and household size. One of their findings indicated that households with a higher number of members showed lower poverty levels than those with fewer members. An examination of this phenomenon pointed to labour supply, which is important in a labour intensive African economy. Kamuzora (200I) also state that modernisation processes have an impact on the correlation between household size and poverty. In less developed countries, with low levels of modernisation, and agriculture as the main economic sector, larger households relate to less poverty in contradiction with other results. However, in more modernised regions, larger households relate to higher levels of poverty, mostly due to limited access to subsistence farming.

In a study by SALGA (2010), it was noted that larger households could have a cost advantage over smaller households. The concept of economies of scale in consumption is relevant. Larger households could attain the same level of welfare on a lower per capita expenditure if compared to smaller households. For example, the cost of housing 
illustrates this point. A household with three members will pay more per capita for housing than a household with five members would. It could be stated that a larger household could possibly achieve a higher standard of living with the same per capita income. The composition of a household is also a factor that needs to be taken into account. The age, gender, and employment status of members of a household have an impact on the poverty status.

The goal of this research is to enrich the literature on poverty research by investigating the most basic economic unit of the South African society, namely the household, and examines the relationship between household size and poverty, as one of the causes of poverty in low-income communities of northern Free State region of South Africa.

\section{Methodology}

The approach followed included a literature review, which served as the theoretical basis of the research, and secondly, a quantitative household survey as part of the empirical component of the research. Findings and recommendations were deducted from the literature review and the empirical phases of the research. A quantitative research approach was used to collect data by means of a community household survey in the northern Free State region during June/July 2013. The study area is also known as the Fezile Dabi region and forms the northern part of the Free State province, South Africa. The study area borders the southern part of the Gauteng province. Twelve low-income communities were included in the survey from communities across the northern Free State region. Selected communities were chosen from all four local municipalities in the region, including Mafube, Metsimaholo, Moqhaka and Ngwathe Local Municipalities. The 12 selected communities are listed in Table 5. A sample of approximately 2900 households were included in the study. Households were selected randomly in each of the communities. A far as possible a 10\% sample size was selected. Table 2 is a summary of selected socioeconomic data for the study region. The region has relative low population densities due to it mostly rural character, with low levels of human development index (HDI). Dependency ratios are high and the region is well provided regarding services such as electricity. The region has low income with most of the areas indicating more than $50 \%$ of the area earning an income of less than RI000 per month.

Table 2: Selected socio-economic data for study region, 2013

\begin{tabular}{|c|c|c|c|c|}
\hline Data indicator & $\begin{array}{l}\text { Mafube area } \\
\text { (including } \\
\text { areas such as } \\
\text { Qalabotjha) }\end{array}$ & \begin{tabular}{|l|} 
Metsimaholo \\
area (including \\
areas such as \\
Zamdela, \\
Metsimaholo, \\
Refengkgotso) \\
\end{tabular} & $\begin{array}{l}\text { Moghaka area } \\
\text { (including areas } \\
\text { such as Moakeng, } \\
\text { Matlwangtlwang, } \\
\text { Rammulutsi, } \\
\text { Mokwallo) }\end{array}$ & $\begin{array}{l}\text { Ngwathe area } \\
\text { (including areas } \\
\text { such as Edenville } \\
\text { Tumahole, } \\
\text { Phiritona, } \\
\text { Kwakwatsi) }\end{array}$ \\
\hline $\begin{array}{l}\text { Total population (growth rate in } \\
2013 \text { in brackets) }\end{array}$ & $60980(0.5 \%)$ & $14 \mid 437(0.8 \%)$ & $176478(0.2 \%)$ & $122099(0.1 \%)$ \\
\hline $\begin{array}{l}\text { Population densities for low-income } \\
\text { areas - number of people per } \\
\text { square km }\end{array}$ & 12.5 & 66.9 & 19.7 & 18.3 \\
\hline HDI of low-income areas & 0.42 & 0.54 & 0.53 & 0.46 \\
\hline Gini-Coefficient & 0.54 & 0.57 & 0.56 & 0.53 \\
\hline $\begin{array}{l}\text { Dependency ratio (per } 100 \text { of } \\
\text { population) }\end{array}$ & 61.1 & 44.3 & 50.5 & 60.2 \\
\hline$\%$ of households with electricity & $84.4 \%$ & $86.4 \%$ & $93.3 \%$ & $92.0 \%$ \\
\hline $\begin{array}{l}\% \text { of households with income less } \\
\text { than RI000 per month in low- } \\
\text { income areas }\end{array}$ & $51.3 \%$ & $38.1 \%$ & $49.2 \%$ & $52.3 \%$ \\
\hline Literacy levels of Black population & $55.7 \%$ & $76.6 \%$ & $72.9 \%$ & $63.3 \%$ \\
\hline
\end{tabular}

Source: Meyer, (2013).

Primary data were collected by means of a questionnaire, which was developed based on a comprehensive literature review. The questionnaire comprised various sections, which include demographics, income and expenditure. Trained fieldworkers, who were familiar with the area, administered the questionnaire to the head of the household in the chosen areas. Prior to the administration of the questionnaire, the specific ward councillors and local community leaders were approached with a request to conduct the study in the area. After permission was granted, potential 
participants were approached. In addition to verbally explaining the purpose of the study, they were referred to a cover letter explaining the purpose of the study. Once informed consent was obtained from the participants, the procedure to complete the questionnaire was outlined. Participants were assured of confidentiality and anonymity. They were also informed that participation was voluntary and they could withdraw at any stage from the study without any repercussions.

The survey data were captured and analysed using the Statistical Package for the Social Sciences (SPSS), version 22 software package. Descriptive statistics were used to report on the data. Pearson's chisquare test was applied in order to determine the existence of significant differences between the two groups, those households below the poverty line and households above the poverty line, in the study area.

\section{Results}

The results of the household survey are reported in this section of the article. A poverty line was calculated for the region including all the communities involved in the survey. The absolute poverty measurement method was used. A poverty line of $\$ 2$ per day, as used by the United Nations (UN), is utilised. The exchange rate, at the time when the research survey was completed, of RII.00 per \$I was used to calculate a daily as well as monthly minimum income per person in the region. At this exchange rate a monthly minimum income of R660 $(\$ 60)$ per person per day has been determined. Table 3 provides the poverty line information for the total study region, which consists of the 12 low-income communities. As could be expected, more than $74 \%$ of the approximately 2900 households included in the survey, live below the poverty line.

Table 3: Poverty line for the study area, 2013

\begin{tabular}{|l|l|l|}
\hline Poverty line & Frequency $(\mathbf{n})$ & Percentage (\%) \\
\hline Households below the poverty line & 2170 & 74.3 \\
\hline Households above the poverty line & 751 & 25.7 \\
\hline Total & 2921 & 100.0 \\
\hline
\end{tabular}

Table 4 is a summary of the total income distribution in the study area. The average income per household per month is determined at RI 458 (\$133), indicating a poor region. The monthly household poverty line for the area was calculated at
R2 508 (\$228). As many as $18 \%$ of all households that formed part of the survey indicated that they had no regular and constant income, while only I2\% indicated relatively high levels of income of more than R4 000 (\$364) per month.

Table 4: Total income distribution in study area, 2013

\begin{tabular}{|l|l|l|l|}
\hline Income category & Frequency $(\mathrm{n})$ & Percentage & Accumulated percentage \\
\hline R 0 - R 249 & 528 & 18.1 & 18.1 \\
\hline R 250-R 749 & 295 & 10.1 & 28.2 \\
\hline R 750-R I499 & 432 & 14.8 & 43.0 \\
\hline R 1500-R 2249 & 819 & 28.0 & 71.0 \\
\hline R 2250-R 2749 & 285 & 9.8 & 80.8 \\
\hline R 2750-R 3999 & 204 & 7.0 & 87.8 \\
\hline R 4000 plus & 358 & 12.3 & 100.0 \\
\hline Total & 2921 & 100.0 & \\
\hline
\end{tabular}

Table 5 indicates household sizes and average household income for the total area and per community. For the total area, the average household size for the 12 communities is 3.8 , which is similar to the South African total average household size. The average household monthly income is a relatively low R384 (\$35) per person in the household. The poverty line of R660 (\$60) per person is nearly twice that of the average income per person in the study region.

Phiritona (area 9) has the largest average households at 4.6 persons, followed by Rafengkgotso (area 6) with an average of 4.2 persons. Matlwangtlwang (area 3) has the smallest average households at 3.4, followed by Zamdela (area 7) with an average household size of 3.5. In terms of average income per person per household, Matlwangtlwang (area 3) had the highest income per person of R507, followed by Metsimaholo (area 5) with an average of R497 per person and Zamdela (area 7) with an average per person income of R485. The area with the lowest per person income was Rammulutsi (area 4) with an average income per person of R253, 
followed by Mokwallo (area 12) with R262 and Phiritona (area 9) at R299 average per month.

Table 5: Household size and average household income for study area (ranking according to average household size), 2013

\begin{tabular}{|c|c|c|c|c|c|}
\hline Area & Municipal area & $\begin{array}{l}\text { Rural or urban } \\
\text { nature of } \\
\text { community }\end{array}$ & $\begin{array}{l}\text { Average } \\
\text { household } \\
\text { size }\end{array}$ & $\begin{array}{l}\text { Average } \\
\text { income per } \\
\text { household }\end{array}$ & $\begin{array}{l}\text { Average } \\
\text { income per } \\
\text { person in } \\
\text { household }\end{array}$ \\
\hline Total area (average) & $\begin{array}{l}\text { Fezile Dabi district } \\
\text { municipal area }\end{array}$ & Generally rural & 3.8 & $R \mid 458$ & R 384 \\
\hline $\begin{array}{l}\text { Matlwangtlwang (area 3) } \\
\text { adjacent to Steynsrus }\end{array}$ & $\begin{array}{l}\text { Moqhaka Local } \\
\text { Municipality }\end{array}$ & Rural & 3.4 & $R \mid 725$ & R 507 \\
\hline $\begin{array}{l}\text { Zamdela (area 7) adjacent } \\
\text { to Sasolburg }\end{array}$ & $\begin{array}{l}\text { Metsimaholo Local } \\
\text { Municipality }\end{array}$ & Urban & 3.5 & $R \mid 696$ & R 485 \\
\hline $\begin{array}{l}\text { Moakeng (area 2) adjacent } \\
\text { to Kroonstad }\end{array}$ & $\begin{array}{ll}\text { Moqhaka } & \text { Local } \\
\text { Municipality } & \end{array}$ & $\begin{array}{l}\text { Semi-rural and } \\
\text { near urban }\end{array}$ & 3.6 & $R \mid 170$ & R 325 \\
\hline Edenville (area 8) & $\begin{array}{l}\text { Ngwathe Local } \\
\text { Municipality }\end{array}$ & Rural & 3.7 & $R \mid 382$ & R 374 \\
\hline $\begin{array}{l}\text { Metsimaholo (area } \\
\text { adjacent to Oranjeville }\end{array}$ & $\begin{array}{l}\text { Metsimaholo Local } \\
\text { Municipality }\end{array}$ & Rural & 3.8 & $R \mid 888$ & R 497 \\
\hline $\begin{array}{l}\text { Kwakwatsi } \begin{array}{l}\text { (area } \\
\text { adjacent to Koppies }\end{array} \\
\text { I0) }\end{array}$ & $\begin{array}{l}\text { Ngwathe Local } \\
\text { Municipality }\end{array}$ & Rural & 3.9 & $R \mid 355$ & R 347 \\
\hline $\begin{array}{l}\text { Tumahole (area II) adjacent } \\
\text { to Parys }\end{array}$ & $\begin{array}{l}\text { Ngwathe Local } \\
\text { Municipality }\end{array}$ & $\begin{array}{l}\text { Semi-rural and } \\
\text { near urban }\end{array}$ & 3.9 & R I 496 & R 384 \\
\hline $\begin{array}{l}\text { Qalabotjha (area I) adjacent } \\
\text { to Villiers }\end{array}$ & $\begin{array}{ll}\text { Mafube } & \text { Local } \\
\text { Municipality } & \\
\end{array}$ & Rural & 4.1 & $R \mid 297$ & R 316 \\
\hline $\begin{array}{l}\text { Rammulutsi (area } \\
\text { adjacent to Viljoenskroon }\end{array}$ & $\begin{array}{l}\text { Moqhaka Local } \\
\text { Municipality }\end{array}$ & Rural & 4.1 & $R \mid 038$ & R 253 \\
\hline $\begin{array}{l}\text { Mokwallo (area I2) adjacent } \\
\text { to Vredefort }\end{array}$ & $\begin{array}{l}\text { Ngwathe Local } \\
\text { Municipality }\end{array}$ & Rural & 4.1 & R I 076 & R 262 \\
\hline $\begin{array}{lll}\text { Rafengkgotso (area } & \text { 6) } \\
\text { adjacent to Deneysville } & \\
\end{array}$ & $\begin{array}{l}\text { Metsimaholo Local } \\
\text { Municipality }\end{array}$ & Rural & 4.2 & $R \mid 360$ & R 324 \\
\hline $\begin{array}{l}\text { Phiritona (area 9) adjacent } \\
\text { to Heilbron }\end{array}$ & $\begin{array}{l}\text { Ngwathe Local } \\
\text { Municipality }\end{array}$ & Rural & 4.6 & $R \mid 374$ & R 299 \\
\hline
\end{tabular}

Table 6 provides for an assessment of household size and its relationship with the poverty line for the total study region. The study area has been divided in two groups, namely households below the poverty line and households above the poverty line. The majority of households are in the three and four persons per household categories, with only limited numbers of households having only one, six and seven persons in the household. With regards to households below the poverty line, the majority of households, namely $84.0 \%$ consist of three to seven persons per household. While for households above the poverty line, households with one to four persons contribute $67.9 \%$ of all households. The statistical analysis indicates a significant statistical difference between the two groups with a chi-square of 519.92 and Pearson's value of 0.000 . 
Table 6: Household size and poverty line for total study area, 2013

\begin{tabular}{|l|l|l|l|}
\hline $\begin{array}{l}\text { Number of people in } \\
\text { household } \\
\text { size) }\end{array}$ & $\begin{array}{l}\text { Households below poverty } \\
\text { line (percentage in in }\end{array}$ & $\begin{array}{l}\text { Households above poverty } \\
\text { line (percentage in in } \\
\text { in } \\
\text { brackets) }\end{array}$ & $\begin{array}{l}\text { Totals (percentage in } \\
\text { brackets) }\end{array}$ \\
\hline One (I) person & $138(6.4)$ & $188(25.0)$ & $326(11.2)$ \\
\hline Two (2) persons & $208(9.6)$ & $213(28.4)$ & $421(14.4)$ \\
\hline Three (3) persons & $460(21.2)$ & $153(20.4)$ & $613(21.0)$ \\
\hline Four (4) persons & $478(22.0)$ & $\mid 45(19.3)$ & $623(21.3)$ \\
\hline Five (5) persons & $364(16.8)$ & $37(4.9)$ & $401(13.7)$ \\
\hline Six (6) persons & $247(11.4)$ & $15(2.0)$ & $262(9.0)$ \\
\hline Seven (7) persons & $275(12.7)$ & $0(0.0)$ & $275(9.4)$ \\
\hline Total & $2170(100.0)$ & $751(100.0)$ & $2921(100.0)$ \\
\hline
\end{tabular}

Table 7 is an indication of the distribution of households between those households below the poverty line and the households above the poverty line in relation to household sizes. From the table it is evident that the majority of households below the poverty line are larger households. On the other hand, the majority of households above the poverty line are smaller households. Figure $I$ is a visual presentation of the same data.

Table 7: Percentage distribution of households per size of household for study area, 2013

\begin{tabular}{|l|l|l|l|}
\hline $\begin{array}{l}\text { Number of people in } \\
\text { household } \\
\text { size) }\end{array}$ & $\begin{array}{l}\text { Percentage of households } \\
\text { below poverty line }\end{array}$ & $\begin{array}{l}\text { Percentage of households } \\
\text { above poverty line }\end{array}$ & Total percentages \\
\hline One (1) person & 42.3 & 57.7 & 100 \\
\hline Two (2) persons & 49.4 & 50.6 & 100 \\
\hline Three (3) persons & 75.0 & 24.9 & 100 \\
\hline Four (4) persons & 76.7 & 23.3 & 100 \\
\hline Five (5) persons & 90.8 & 9.2 & 100 \\
\hline Six (6) persons & 94.3 & 5.7 & 100 \\
\hline Seven (7) persons & 100.0 & 0.0 & 100 \\
\hline $\begin{array}{l}\text { Total number of } \\
\text { households }\end{array}$ & 2170 & 751 & $2921(100.0)$ \\
\hline
\end{tabular}

Figure I: Percentage distribution of households sizes in study area, 2013

$\mathbf{\square} \%$ of households below the poverty line $\quad$ [\% of households above the poverty line

80

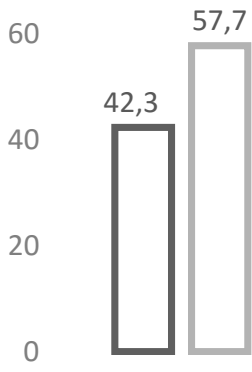

40

20

0

One person household

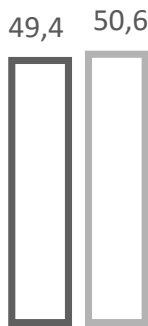

two person household
75

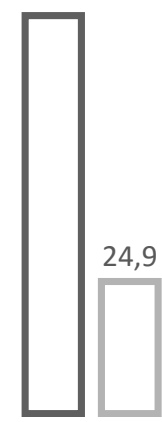

three person household

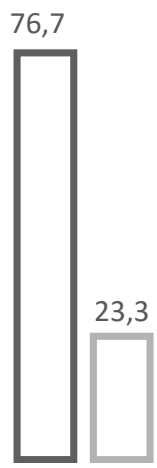

Four person household

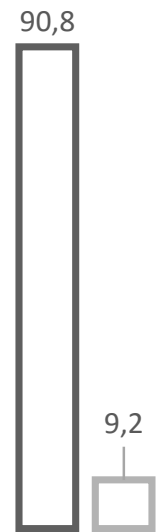

Five person household

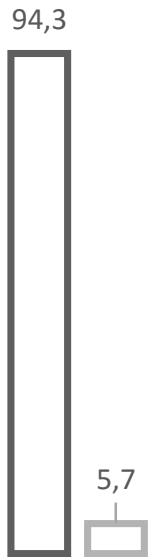

Six person household
100

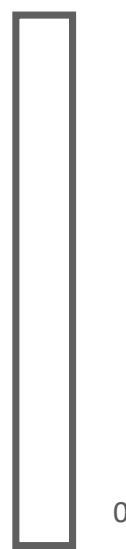

Seven person household 
Table 8 is a summary of the data for all 12 of the communities included in the survey. The percentages of households living below the poverty line are presented. Poverty levels range from $58 \%$ at Metsimaholo (area 5) to 91.9\% for Mokwallo (area 12). Household size and povertylevels were correlated. The two groups, those households below the poverty line and those households above the poverty line, were compared to determine if the levels of poverty differs if compared to household size. The comparison indicates significant statistical differences for all communities, except for Matlwangtlwang (area 3). The reason for this occurrence could possibly explained by the fact that the community is located the furthest south of all the communities and has better access to pockets of land, allowing some farming activities and labour for family members. All the other communities presented significant differences between households below and above the poverty line regarding household size. P-values and chi-square values are indicated in Table 8. The data presented indicates that larger households (more than 4 persons) are generally poorer than smaller households in the study region are.

Table 8: Summary of statistics per area in total study area, 2013

\begin{tabular}{|c|c|c|c|c|}
\hline Community & $\begin{array}{l}\text { Total Number } \\
\text { of households }\end{array}$ & $\begin{array}{l}\text { Households } \\
\text { below poverty } \\
\text { line (\%) }\end{array}$ & $\begin{array}{l}\text { Description of key statistics for } \\
\text { larger households of } 4 \text { to } 7 \\
\text { people per household. }\end{array}$ & $\begin{array}{l}\text { P-value } \\
\& \quad \text { chi- } \\
\text { square }\end{array}$ \\
\hline Qalabotjha (area I) & 166 & 81.3 & $\begin{array}{l}\text { Below the poverty line }=\mathbf{6 9 . 6 \%} \\
\text { Above the poverty line }=22.6 \%\end{array}$ & $\begin{array}{l}0.000 \quad \& \\
34.56\end{array}$ \\
\hline Moakeng (area 2) & 363 & 79.3 & $\begin{array}{l}\text { Below the poverty line }=59.7 \% \\
\text { Above the poverty line }=10.7 \%\end{array}$ & $\begin{array}{ll}0.000 \quad \& \\
93.62\end{array}$ \\
\hline Mat/wangtlwang (area 3) & 50 & 68.0 & $\begin{array}{l}\text { Below the poverty line }=\mathbf{2 9 . 4 \%} \\
\text { Above the poverty line }=37.5 \%\end{array}$ & $\begin{array}{l}0.504 \quad \& \\
5.31\end{array}$ \\
\hline Rammulutsi (area 4) & 93 & 88.2 & $\begin{array}{l}\text { Below the poverty line }=63.4 \% \\
\text { Above the poverty line }=9.1 \%\end{array}$ & $\begin{array}{l}0.000 \& \\
31.115\end{array}$ \\
\hline Metsimaholo (area 5) & 48 & 58.3 & $\begin{array}{l}\text { Below the poverty line }=\mathbf{8 5 . 7} \% \\
\text { Above the poverty line }=\mathbf{3 0 . 0 \%}\end{array}$ & $\begin{array}{ll}0.001 & \& \\
21.825 & \\
\end{array}$ \\
\hline Rafengkgotso (area 6) & 154 & 77.3 & $\begin{array}{l}\text { Below the poverty line }=69.7 \% \\
\text { Above the poverty line }=45.7 \%\end{array}$ & $\begin{array}{ll}0.006 \quad \& \\
17.95\end{array}$ \\
\hline Zamdela (area 7) & 1000 & 65.0 & $\begin{array}{l}\text { Below the poverty line }=\mathbf{6 0 . 0 \%} \\
\text { Above the poverty line }=\mathbf{2 7 . 1} \%\end{array}$ & $\begin{array}{l}0.000 \& \& \\
194.916\end{array}$ \\
\hline Edenville (area 8) & 192 & 75.5 & $\begin{array}{l}\text { Below the poverty line }=60.7 \% \\
\text { Above the poverty line }=25.5 \%\end{array}$ & $\begin{array}{l}0.000 \& \\
38.041\end{array}$ \\
\hline Phiritona (area 9) & 103 & 86.4 & $\begin{array}{l}\text { Below the poverty line }=77.5 \% \\
\text { Above the poverty line }=21.4 \%\end{array}$ & $\begin{array}{l}0.000 \& \\
25.461\end{array}$ \\
\hline Kwakwatsi (area I0) & 145 & 77.9 & $\begin{array}{l}\text { Below the poverty line }=61.9 \% \\
\text { Above the poverty line }=34.4 \%\end{array}$ & $\begin{array}{l}0.001 \& \\
22.579\end{array}$ \\
\hline Tumahole (area II) & 393 & 79.1 & $\begin{array}{l}\text { Below the poverty line }=61.7 \% \\
\text { Above the poverty line }=30.5 \%\end{array}$ & $\begin{array}{l}0.000 \& \\
37.153\end{array}$ \\
\hline Mokwallo (area I2) & 112 & 91.9 & $\begin{array}{l}\text { Below the poverty line }=62.1 \% \\
\text { Above the poverty line }=0.0 \%\end{array}$ & $\begin{array}{l}0.000 \& \\
49.745\end{array}$ \\
\hline
\end{tabular}

\section{Discussion and findings}

The 12 communities included in the study are typical low-income townships in the South African context. Poverty is rife in these areas with close to $75 \%$ of all households living below the poverty line. These townships are characterised by limited access to economic and work opportunities, lack of basic services, lack of community facilities and isolation from the rest of the urban fabric.

The isolated locality of these communities is mostly as a result of the apartheid past, as the main reason for lack of economic opportunities and a lack of income (Madell, 2008). The low-income levels are proven by the low average income of only RI 458 per household per month in the study region. The average monthly household income in South Africa in 
2013 was RI5 232 (Trading Economics, 20I5) and a national poverty line of RI 683 per household per month (StatsSA, 2014). Low levels of literacy (see Table 2) in the study region also contribute to the lack of income. In most low-income areas of the study region, more than $50 \%$ of all households included in the survey had less than RI 000 household income per month (see Table 2).

Globally, household sizes have been declining over the long run (Koulovatianos et al., 20l0). In the study region, larger than average households have been recorded of 3.8 people per household. The average household size in South Africa has decreased from 3.8 in 2001 to 3.4 people per house hold in 2011 (StatsSA, 2014). Household sizes however differs globally according to the OECD (20/4). Europian countries such as Denmark, Finland, Germany and Norway have household sizes of 2.1 on average, while some developing countries such as Mexico and Turkey have larger household sizes of 4.0 and more.

The Phiritona community (area 9) has the highest average household size of 4.6, while Matlwengtlwang (area 3) has the smallest household size of 3.4. Communities located closer to large towns such as Zamdela, located adjacent to Sasolburg, Moakeng, located close to Kroonstad, and Tumahole, located in the vicinity of Parys, all have relatively smaller household sizes of 3.5, 3.6 and 3.9 respectively, if compared to the communities that are located close to small towns. A positive relationship exists in the study region between "ruralness" and large household sizes. This finding is supported by similar findings by Kamuzora and Gwalema (1998). This phenomenon could be explained that rural communities have easier access to land. Household members could be described as labour units, working on patches of subsistence farming land (Kamuzora, 200I).

The results of the survey in the study area point to a relationship between household size and poverty; the larger the household, the higher the level of poverty. This finding is confirmed by similar findings by Lanjouw and Ravallion (1995) and Sekhampu, (20/3). This positive correlation was proven statistically with the results indicated in Tables 5, 6 and 7. This relationship could be explained due to the spatially isolated localities of the communities, the very high levels of unemployment, and lack of access to land, services and opportunities. Most households in these low-income communities are also immobile, with a lack of public transport. All 12 communities, except Matlwengtlweng (area 3) presented a strong relationship between household size and poverty. It is not clear why area 3 did not show a correlation between large households and high levels of poverty, but it could be the fact that general levels of poverty in this community are lower than the regional average, as well as the fact that household sizes are also the smallest in the study area. The area is also the southern most community in the study region and the community has access to land.

\section{Recommendations}

The following recommendations are listed within the context of household size and poverty, with a focus on dynamic policy development. Population policy development needs to focus on the principle that economic growth should generally be higher than population growth for successful economic development (Todaro, 201 I). Ahlburgh (1998) states that people cannot be prescribed regarding household size. Policy initiatives need to focus on education regarding reproductive health, with child spacing, rather than a prescriptive policy, which limits household size (UNECA, 1999). This study has presented evidence from the study region specifically, that larger households relate to higher levels of poverty as presented in Table 7 and 8. Large poor households generally have relatively high numbers of dependents.

Implementation policies to reduce the size of poor households can include a variety of initiatives. Such initiatives can include increased public provision of basic needs such as housing, basic services, and access to social security programmes (Mullahy \& Wolfe, 2000; Bongaarts, 200I). Other aspects that could be addressed include education on improved financial and income management, and effective provision of community facilities, as well as access to assets such as land and economic opportunities.

Lastly, the following three policy support factors should be given attention. First, women and youthheaded households should receive special attention and support (Anyanwu, 20/3). Secondly, local poor communities know their areas better than anybody else, and intensive and quality public participation should precede policy formulation. Lastly, all efforts should be made to improve community capacity.

\section{Conclusion}

The aim of the study was to investigate the relationship between household size and poverty. Global research is indicating significant evidence of a positive relationship between household size and poverty. It was found that areas with limited modernisation, larger households present lower levels of poverty due to possible access to land and subsistence farming (Kamuzora, 200I). On the other hand, in regions such as the study region, with advanced levels of urbanisation and modernisation, 
larger households generally have higher levels of poverty.

This study confirms the latter phenomenon in the northern Free State. The study region consists of mostly rural but also a few more urbanised communities. The results confirm that larger households relate to higher levels of poverty, with rural communities also having larger households. South Africa has relatively high levels of modernisation and limited access to land with resulting limited subsistence farming in contrast with most other African countries.

The limitation of the study is that household compositions were not taken into account, but a future study will address this issue. The research provides some solutions for improved policy development. The results of the study contribute to the debate of household size and poverty on a local level.

\section{References}

Ahlburgh, D.A, 1998. Julian Simon and the population growth debate. Population and Development Review. 24(2), 317-328.

Anand, S. 1977. Aspects of poverty in Malaysia. Review of Income and Wealth, 23, I-16.

Anyanwu, J.C. 2013. Marital status, household size and poverty in Nigeria: evidence from the 2009/2010 survey data. African Development Bank Working Paper Series No. 180.

Baiyegunhi, L.J.S., \& Fraser, G.C.G. 2010. Determinants of household poverty dynamics in rural regions of the Eastern Cape Province, South Africa. Poster presented at the Joint 3rd African Association of Agricultural Economists (AAAE) and 48th Agricultural Economists Association of South Africa (AEASA) Conference, Cape Town, South Africa, 19-23 September.

Bigsten, A., Kebede, B., Shimeles, A., \& Taddesse, M. 2003. Growth and poverty reduction in Ethiopia: Edidence from household panel surveys. World Development, 3I(I), 87-106.

Bongaarts, J, 200I. Household size and composition in the developing world in the 1990s. Population Studies: A Journal of Demography, 55(3), 263279.

Borsch-Supan, A. 1986. Household formation, housing prices and public policy impacts. Journal of Public Economics. 30, I45-164.

Bradbury, M., Peterson, M.N., \& Liu, J. 2014. Longterm dynamics of household size and their environmental implications. Population and environment. New York: Springer.

Dubey, A., Gangopadhyay, S. \& Wadhwa, W. 1999. Female-headed Households in India: Incidence,
Poverty and Socio-economic Characteristics. Planning and Policy Research Unit Paper. New Delhi. Indian Statistical Institute.

Easterlin, R.A. 1967. The effects of population growth on the economic development of developing countries. The Annals of the American Academy of Political and Social Sciences, 369, 98108.

Fishlow, A. 1972. Brazilian size distribution of income. American Economic Review, 62, 391402.

Jalan, J., \& Ravallion, M. 1998. Determinants of transient and chronic poverty: evidence from rural China. Policy Research Working Paper 1936, Washington D.C.: Research Development Group of the World Bank.

Kamuzora, C.L., \& Gwalema, S. 1998. Aggravation of poverty in rural Bukoba district, Tanzania: labour constraints, population dynamics and the AIDS epidemic. Research Report. Dar Es Salaam: REPOA.

Kamuzora, C.L. 200I. Poverty and family size patterns: omparison across African countries. Research Report no 01.3. Dar Es Salaam: REPOA. Mkuki Nyota Publishers.

Kanbur, R., Younger, S., \& Cichello, P. 2003. Analysis and Measurement of Poverty and Inequality. Technical Assistance Course Study Guide. University of Cape Town.

Klasen, S, 2000. Measuring poverty and deprivation in South Africa. Review of Income and Wealth Series, 46(I), 33-58.

Klinenberg, E, 2012. Going solo: The extra-ordinary rise and surprising appeal to live alone. New York: Penguin Press.

Koulovatianos, C., Minkovsk, P., \& Schroeder, C. 20I0. Per capita increase versus household needs adjusted income: a cross country comparison, LIS Working Paper Series, No 528. Luxembourg.

Lanjouw, P., \& Ravallion, M. 1995. Poverty and household size. The Economic Journal. 105(433), |415-1434.

Latour, B. 2004. Politics of nature: how to bring sciences into democracy. Cambridge: Harvard University Press.

Madell, C, 2008. Relevance of spatial planning interventions in reducing poverty and marginalization of South African townships. Paper read at the Planning Africa Conference held in Johannesburg on 14 to 16 April 2008, Johannesburg, 50-59.

May, J., \& Norton, A. 1997. A difficult life: the perception and experience of poverty in South Africa. Social Indicators Research, 4I(I-3), 95II8. 
May, J., Budlender, D., Mokate, R., Rogerson, C., \& Stavrou, A. 1998. Poverty and inequality in South Africa. Report prepared for the Office of the Deputy President, Republic of South Africa, Pretoria. Retrieved from: http://www.polity.org.za/govdocs/reports/poverty .html. Date of access: 4 April 2014.

Meyer, D.F. 2013. An exploration of revitalization strategies for rural areas: The case of the Northern Free State. PhD thesis. North-West University. Van Der Bijlpark.

Micheal, R.T., Fuchs, V.R., \& Scott, S.R. 1980. Changes in the propensity to live alone, 19501976. Demography, 17, 39-56.

Mullahy, J. \& Wolfe, B. 2000. Health Policies for the Non-Elderly Poor, In

Understanding Poverty in America: Progress and Problems, edited by S. Danziger, R.

Haveman and B. Wolfe.

Okurut, F.N., Odwee, J.A.O., \& Adebua, A. 2002. Determinants of Regional Poverty in Uganda. AERC Research Paper 122. Nairobi. African Economic Research Consortium.

Orbeta, A.C, 2005. Poverty, vulnerability and family size: evidence from the Philippines. Asian Development Bank Institute Discussion Paper No. 29. Tokyo.

Organisation for Economic Coordination and Development (OECD). 20II. Doing better for families.

http://www.oecd.org/els/soc/4770 I I 8.pdf. Date of access: 5 November 2015.

Organisation for Economic Coordination and Development (OECD). 20I4. Family size and household composition. Social Policy Division. Retrieved from: www.oecd.org/social/family/database. Date of access: 5 November 2015.

Perlman, R. 1976. The Economics of Poverty. New York. McGraw-Hill Book Company.

Poswa, N. 2008. Strategic development information and GIS department, characteristics of households living in poverty. City of Cape Town. Retrieved from:

http://www.capetown.gov.za/en/stats/CityReports Documents.pdf Date of access: 5 April 2014.

Rakodi, C. 1995. Poverty lines or household strategies. Habitat International, 19(4), 407-426.

SALGA see South African Local Government Association

Schiller, B.R, 1995. The economics of poverty and discrimination. New Jersey: Prentice Hall.

Sekhampu, T.J, 2013. Determinants of Poverty in a South African Township. Journal of Social Sciences, 34(2), I45-I53.
South African Local Government Association (SALGA), 20I0. Estimating a poverty line: an application of free basic municipal services in South Africa. Johannesburg.

SPII see Studies in Poverty and Inequality Insitute

Studies in Poverty and Inequality Institute (SPII), 2007. The measurement of poverty in South Africa: Key issues, Working paper no I. Richmond. Johannesburg.

Schwabe, C. 2004. Fact sheet: poverty in South Africa. Pretoria: Human Sciences Research Council (HSRC).

Statistics South Africa. 20I4. Poverty trends in South Africa. Report no 03-10-06. Pretoria. Government printer.

Todaro, M.P., \& Smith, S.C., 20II. Economic development. IIth ed. Essex: Pearson Education Limited.

Trading Economics. 2015. South Africa average monthly gross wage, 2004 to 2015. Retrieved from: http://www.tradingeconomics.com/southafrica/wages. Date of access: 30 October 2015.

United Nations (UN), 2009. Income poverty and unsatisfied basic needs. Mexico: UN.

United Nations Population Fund (UNPF). (1999). Press summary: state of world population 1999: The Cairo Concensus. UN.

United Nations Economic Commission for Africa (UNECA), 1999. Meeting the development challenges in Africa. Opening address to the joint Conference of African Ministers of Finance and Economic Development Planning by K. Y. Amoako, Executive Secretary of ECA, Addis Ababa, 6 May 1999.

Virola, R.A., \& Martinez, A.M. 2007. Population and poverty nexus: Does family size matter? Paper presented at 10th National Convention on Statistics (NCS), EDSA Shangri-La Hotel, I-2 October.

White, H. \& Masset, E. 2003. The importance of household size and composition in structing poverty profiles: An illustration from Vietman. Development and Change, 34(I), I05-I 26.

Widyanti, W., Suryahadi, A., Sumarto, S., \& Yumna, A. 2009. The relationship between chronic poverty and household dynamics: evidence from Indonesia. Jakarta: SMERU Research Institute.

Woolard, I. \& Klasen, S. 2005. Determinants of income mobility and household poverty dynamics in South Africa. The Journal of Development Studies, 4I5, 865-897.

World Bank. 1990. World Development Report, 1990. London. Oxford University Press.

World Bank, 1995. Key indicators of poverty in South Africa. Analysis prepared for the office of the 
African Population Studies Vol. 30, No.2, 2016

RDP. Pretoria: South Africa Communication Services.

World Bank, 20I4. Country and lending groups. Retrieved from:

http://data.worldbank.org/about/country-

classifications/country-and-lending-

groups\#Upper middle income Date of Access:

16 May 2014.
Yu, E., \& Liu, J. 2007. Environmental impact of divorce. Proceedings of the International Academy of Sciences of the USA, 104(5I), 20629-20634. 